\title{
A Comparative Study on the Biofilm Formation of Enterobacter agglomerans and Serretia rubideae in Different Environmental Parameter under Single Culture Condition
}

\author{
Jabun Naher ${ }^{1}$, Shahidul A. Chowdhury1, Abdullah A. Mamun², Nuruddin Mahmud1, \\ Wahhida Shumi1 ${ }^{*}$, Ruhul A. Khan² \\ ${ }^{1}$ Department of Microbiology, University of Chittagong, Chittagong, Bangladesh \\ ${ }^{2}$ Institute of Radiation and Polymer Technology, Bangladesh Atomic Energy Commission, Dhaka, Bangladesh \\ Email: ${ }^{*}$ wshumi@gmail.com
}

Received 7 February 2014; revised 21 February 2014; accepted 28 February 2014

Copyright (C) 2014 by authors and Scientific Research Publishing Inc.

This work is licensed under the Creative Commons Attribution International License (CC BY).

http://creativecommons.org/licenses/by/4.0/

(c) (†) Open Access

\begin{abstract}
The biofilm formation by two opportunistic pathogens Enterobacter agglomerans and Serretia rubideae on different environmental parameter under single culture condition was compared. Biofilm clone formation unit (CFU) counting revealed that the number of Enterobacter was larger than Serretia after 24-h incubation. Consistent with this result, measurement of crystal violet staining of bacteria attached on the test tubes showed that the absorbance at $600 \mathrm{~nm}$ enhanced 2 times in Enterobacter than Serretia under optimum growth condition. Experiments with different environmental conditions such as incubation period, temperature, $\mathrm{pH}, \mathrm{NaCl}$ concentration $\left(\mathrm{a}_{\mathrm{w}}\right)$ and medium ingredient contents for both organisms were carried out in Luria Bertani (LB) broth. The results indicated that Enterobacter grew well at $37^{\circ} \mathrm{C}$ after $24 \mathrm{~h}$ but Serretia grew well at $27^{\circ} \mathrm{C}$ after 48-h and $0.5 \% \mathrm{NaCl}$ concentration was found optimum for both. On the other hand, $0.5 \%$ medium content and pH 5 was found optimum for Enterobacter whereas $2 \%$ medium content and $\mathrm{pH} 7$ for Serretia.
\end{abstract}

Keywords

Pathogens; Enterobacter agglomearns; Serretia rubidaea; Biofilm; Nosocomial Infection

\footnotetext{
${ }^{*}$ Corresponding author.
}

How to cite this paper: Naher, J., et al. (2014) A Comparative Study on the Biofilm Formation of Enterobacter agglomerans and Serretia rubideae in Different Environmental Parameter under Single Culture Condition. Open Journal of Medical Microbiology, 4, 70-76. http://dx.doi.org/10.4236/ojmm.2014.41008 


\section{Introduction}

Enterobacter and Serretia both genus are Gram-negative, rod-shaped bacteria of the family Enterobacteriaceae. They are classified as facultative anaerobes which means that they are able to thrive in both aerobic and anaerobic environments [1] [2]. Serretia is responsible for about $2 \%$ of nosocomial infections of the bloodstream, lower respiratory tract, urinary tract, surgical wounds, skin and soft tissues in adult patients. They are unique by their production of three enzymes such as DNase, lipase and gelatinase [3].

On the other hand, many species of Enterobacter possess flagella and have the ability to synthesize an enzyme known as ornithine decarboxylase. They are nosocomial opportunistic pathogens that are causing more infections including up to $5 \%$ of hospital-acquired septicemias, $5 \%$ of nosocomial pneumonias, $4 \%$ of nosocomial urinary tract infections, and $10 \%$ of postsurgical peritonitis cases [4]. Some symptoms of Enterobacter infections include bacteremia, lower respiratory tract infections, skin infections, soft tissue infections, urinary tract infections, endocarditis, intra-abdominal infections, septic arthritis, osteomyelitis, and ophthalmic infections. These bacteria also have some usefulness such as Enterobacter cloacae is used in biological control of plant diseases.

Bacteria can live in planktonic (free living) or sessile phenotype. When free living bacteria attach to surface, they begin to proliferate themselves, aggregate and secrete exo-polysaccharide (EPS) that helps to sequester nutrients and other planktonic cells. The aggregated cell-EPS complex will finally mature and form a water channel, containing mushroom-like three layer structure, termed as biofilm [5]-[8]. Depending on the species, micro-colony may be composed of $10 \%$ - 25\% cells and $75 \%$ - 90\% EPS matrix, and the matrix material often appears to be most dense in the area closest to the core of the micro-colony [9]. Bacteria inside the biofilm showed properties that are dramatically different from their free-living style. Biofilm structure enhances bacterial communication, nutrient exchange and metabolic efficiency of the community. Thereby this structure confers the bacteria more resistant to antibiotics and host immune attack. Floating bacteria that in some case are released from mature biofilms will aggravate infections or result in acute attack to host and eventfully lead to repeated infections [10] [11]. Vaccines developed against planktonic bacteria prevented epidemic diseases, like diphtheria and typhoid, and antibiotics developed against planktonic cells saved the lives of millions of people with acute diseases like septicemia and gangrene. The environmental genera (Pseudomonas, Serratia, Legionella, etc.) are responsible for nosocomial infection now began to displace the specialized pathogens of most common bacterial diseases and they often gave rise to general exacerbations characterized by very acute and even lifethreatening symptoms [9].

The purpose of the present research was to compare the degree of biofilm formation by two opportunistic pathogens Enterobacter agglomearns and Serretia rubidaea in different environmental condition.

\section{Materials and Methods}

\subsection{Materials}

For this research, subcultures of previously isolated bacteria were used. These cultures were kept preserved in the Laboratory of Microbiology Department, Chittagong University. The preserved cultures were then enriched in nutrient broth for $4 \mathrm{~h}$ at $37^{\circ} \mathrm{C}$ temperature. To confirm the purity of the isolates, the enriched culture were seeded onto Nutrient Agar (NA) medium following streak plate method and ensure the presence of similar types of colonies in the medium. To facilitate the handling of the isolates they were designated as JN and NW. One set of purified bacterial subcultures were preserved as stock culture in polyethylene bag at $4^{\circ} \mathrm{C}$ temperature. Occasional sub-culturing (after 3 to 4 weeks) were maintained to keep the cultures in active condition and used for further studies.

\subsection{Identification}

With an aim to characterize the selected bacterial isolates the renowned morphological and biochemical methodswere followed. Based on the results or characteristics obtained from following experiments, the isolates were identified. During identification, the characteristics of the isolates were compared with standard description given in "Bergey’s Manual of Determinative Bacteriology" [12]. 


\subsection{Biofilm Production and Screening Procedure}

Biofilm production was done by the standard method mentioned in the literature [13]. Here, one loopful from the subcultures of both isolates were inoculated in $5 \mathrm{ml} \mathrm{LB}$ broth containing test tubes and incubated for $4 \mathrm{~h}$ at $37^{\circ} \mathrm{C}$ for enrichment. Then the suspension were dispensed in different test tube at inoculum to medium ratio of 1:20 and incubated at $37^{\circ} \mathrm{C}$ temperature for different periods (24, 48, 72, 96 and 120 hours respectively).After incubation, biofilm was seen by staining procedure. The dye used for this purpose was ammonium oxalate crystal violet. In this assay, after the respective incubation times, the culture medium was discarded from the tubes carefully. Then the tubes washed with sterile distilled water to remove loosely associated bacteria and air dried for $30 \mathrm{~min}$. The tubes were stained with $1 \%$ ammonium oxalate crystal violet solution and left for $30 \mathrm{~min}$ at room temperature. Tubes were then inverted to remove the crystal violet and rinsed twice with sterile distilled water to remove excess crystal violet (CV). Five $\mathrm{ml}$ of $95 \%$ ethanol solution was added in each tube which can act as a destining agent and incubated for 30 minute at room temperature. This could dissociate the biofilm forming cells and solubilized the remaining crystal violet attached to the cell. The absorbance of the retained dye was measured by spectrophotometer at $600 \mathrm{~nm}$.

\subsection{Different Parameters for Biofilm Development}

For the detection of optimum growth parameter the organisms were inoculated in different media parameters at inoculums to medium ratio of 1:20.

\subsection{Determination of the Optimum Temperature}

For the detection of optimum temperature both organisms were inoculated in different $5 \mathrm{ml}$ sterile LB broth containing screw cap tubes. Then the tubes were incubated at different temperatures $\left(10^{\circ} \mathrm{C}, 27^{\circ} \mathrm{C}, 37^{\circ} \mathrm{C}\right.$ and $\left.45^{\circ} \mathrm{C}\right)$ for $24 \mathrm{~h}$. After incubation the biofilm was assayed by the modified method [14].

\subsection{Determination of the Optimum Incubation Period}

The effects of incubation periods on the biofilm formation by selected isolates were also determined. For this purpose, LB media was prepared and transferred $5 \mathrm{ml}$ of media in each of 6 inch screw cape tube. After autoclaving the tubes were inoculated with single organism and incubated for different periods (such as $24,48,72$, 96 and $120 \mathrm{~h}$ ) at optimum temperature for each isolates. After growth the biofilm density was measured by the modified method [14]. The effects of incubation periods on the biofilm formation were recorded.

\subsection{Determination of the Optimum pH}

To observe the effects of media $\mathrm{pH}$ on the biofilm formation by selected isolates, Luria Bertani (LB) media were prepared in buffer solution. After adding the ingredient of LB broth, the $\mathrm{pH}$ of the media was adjusted to the specific $\mathrm{pH}$ points to $\mathrm{pH}$ 3, 4, 5, 6, 7, 8 and 9. Then $5 \mathrm{ml}$ of medium from each $\mathrm{pH}$ was transferred to 6 inch screw cape tubes. After autoclaving the tubes were inoculated with single organism, and incubated at optimized conditions for each isolates. After incubation the biofilm was assayed by the modified method. The $\mathrm{pH}$ effects on the biofilm formation were recorded.

\subsection{Determination of the Optimum Salt Concentration}

Luria Bertani (LB) medium was prepared with different concentrations of $\mathrm{NaCl}(0 \%, 0.5 \%, 1 \%$ and $2 \%$ concentration). Then $5 \mathrm{ml}$ of media with different salt concentrations was transferred in each of 6 inch screw cape tube and sterilized. The medium was inoculated with organisms and incubated in optimum condition for each isolates. After growth the biofilm was measured by the modified method [14]. Effects of salt concentration on the biofilm formation were noted.

\subsection{Determination of the Optimum Medium Concentration}

LB medium was prepared using different ingredients at a changed concentration and sterilized in screw cap tube. Then the medium was inoculated with single microorganism and incubated keeping all other experimental con- 
ditions at optimum. After incubation the biofilm was assayed by the modified method. The effects of medium concentration were documented.

\subsection{Enumeration of Total Viable}

The total viable bacteria were enumerated for both microorganisms.

\subsubsection{Serial Dilution}

Five sterile test tubes were taken containing $9 \mathrm{ml}$ sterile water. Test tubes were labeled by $10^{-1}$ to $10^{-5}$. Before making any dilution, each of the isolate enriched in $5 \mathrm{ml} \mathrm{LB}$ broth for $4 \mathrm{~h}$ at $37^{\circ} \mathrm{C}$ and shaken vigorously. Then $1 \mathrm{ml}$ from each enriched isolates was added to a test tube containing $9 \mathrm{ml}$ of sterile water and thoroughly mixed to get a $10^{-2}$ dilution. In such a way serial dilution of isolates were made up to $10^{-5}$.

\subsubsection{Standard Plate Count (Pour Plate Method)}

$1 \mathrm{ml}$ of each dilution was placed on sterile Petri plates by sterile pipette. Approximately $15 \mathrm{ml}$ of sterilized melted and cooled $\left(45^{\circ} \mathrm{C}\right)$ nutrient agar (NA) was poured into the plates. The plates were rotate by hand for several times in the clockwise, anticlockwise, and crosswise direction for equal distribution of the media. Then the plate was allowed to solidify. After solidification of the media, the plates were incubated at $37^{\circ} \mathrm{C}$ for $24 \mathrm{~h}$ in an incubator at inverted position. Two plates corresponding to one dilution were done. After incubation colonies were counted. The arithmetic average of two counts for each dilution was taken and multiplies by the respective dilution factor to get the result [15]. The calculated result expressed as colony forming unit (CFU).

\section{Results and Discussion}

The morphological, cultural and biochemical characteristics of the preserved isolates were studied to identify it up to species. Morphological characteristics include size and shape, arrangement of the cells, presence or absence of spores, irregular forms, acid fast reaction, gram reaction etc. Cultural and physiological characteristics include temperature tolerance, salt tolerance, IMViC test, $\mathrm{H}_{2} \mathrm{~S}$ production, nitrate reduction test, fermentation of different carbohydrates etc. All these characteristics were then compared with the standard description of Bergey's Manual of Determinative Bacteriology [12] and found that the isolates belonged to the genus Enterobacter and Serretia and provisionally identified as Enterobacter agglomerans and Serretia rubidaea.

The optimum growth parameters for biofilm formation by Enterobacter and Serretia between 24 and $48 \mathrm{~h}$ incubation period at different temperatures showed that the OD value was 2 times higher after $24 \mathrm{~h}$ at $37^{\circ} \mathrm{C}$ temperature for Enterobacter where 4 times higher after $48 \mathrm{~h}$ at $27^{\circ} \mathrm{C}$ for Serretia. Here negative control was deducted from the test absorbance. The results are presented in Figure 1.

A large difference was observed in biofilm formation in various $\mathrm{pH}$ ranges. After adjusting the media $\mathrm{pH}$ such as $\mathrm{pH}$ 4, 5, 7, 8 and 9 (before autoclave) it was found that at $\mathrm{pH}$ 7, the growth of Serretia was increased while Enterobacter showed extended growth in $\mathrm{pH} 5$ as shown in Figure 2.

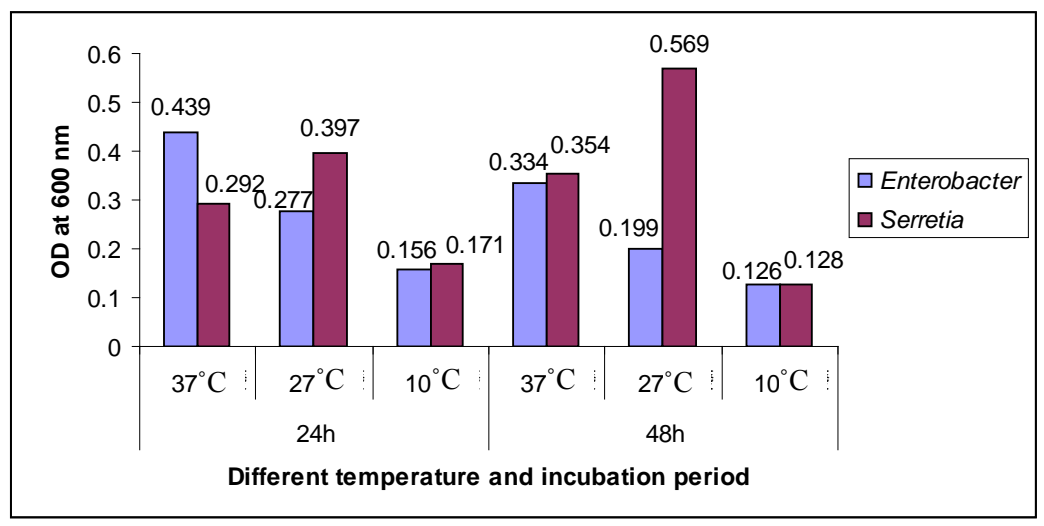

Figure 1. Biofilm formation as measured by crystal violet absorbance at $600 \mathrm{~nm}$ after 24 and 48 hours incubation period at different temperatures. 
The effects of salt concentration on the biofilm formation showed that the medium with $0.5 \%$ salt having a good growth for both Serretia and Enterobacter. But when the salt concentration was doubled, they showed less absorbance. The findings are represented in Figure 3.

Other parameter such as medium content showed that at 0.5\% media content Enterobacter grew well. But Serretia grew well at 2\% media content as described in Figure 4.

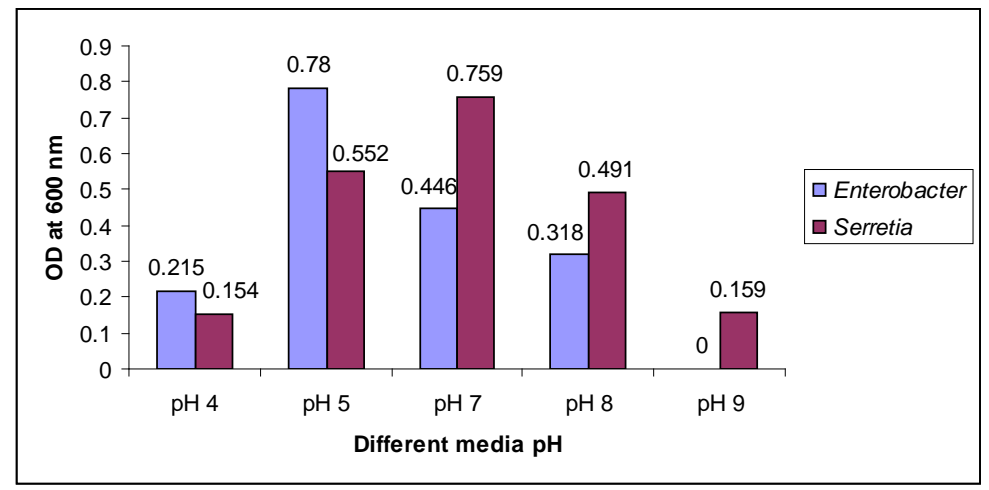

Figure 2. Biofilm formation as measured by crystal violet absorbance at 600 $\mathrm{nm}$ after optimum incubation period with optimum temperature and different media $\mathrm{pH}$.

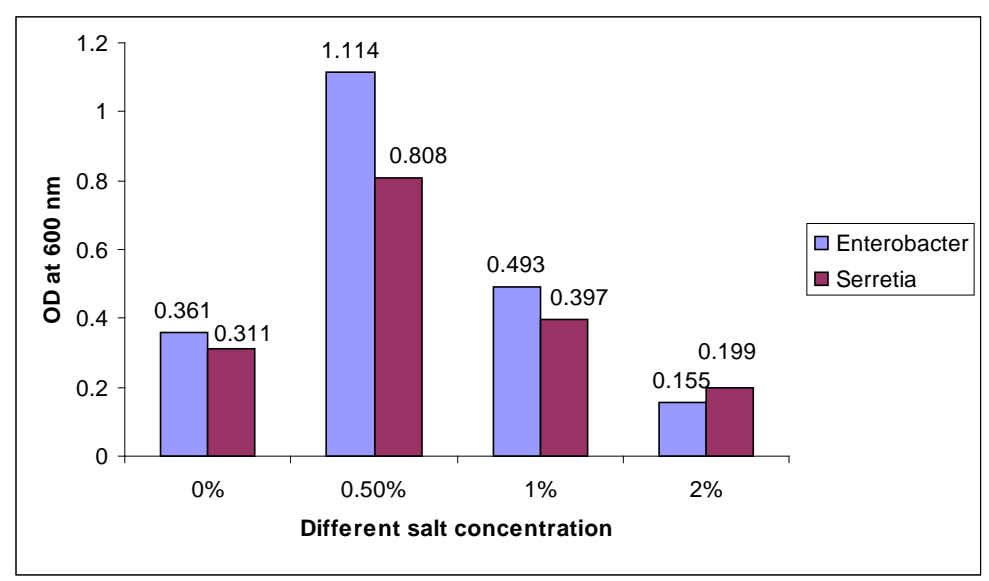

Figure 3. Biofilm formation as measured by crystal violet absorbance at 600 $\mathrm{nm}$ after optimum incubation period with different salt concentration.

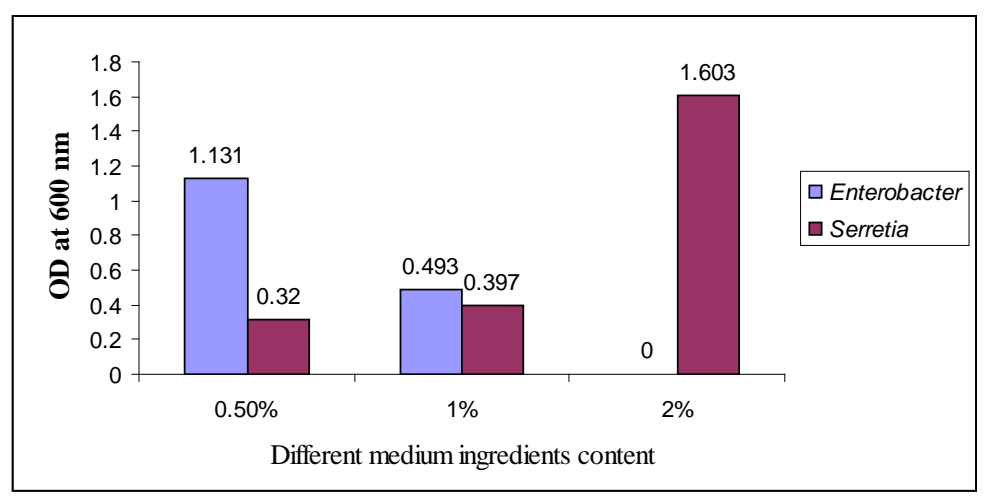

Figure 4. Biofilm formation as measured by crystal violet absorbance at 600 $\mathrm{nm}$ after optimum incubation period with different medium content. 


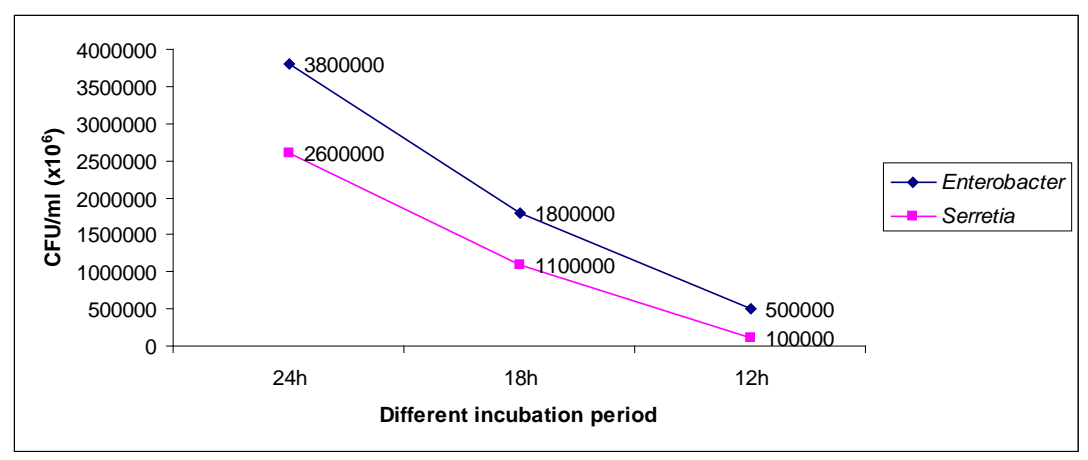

Figure 5. Total count of the isolated microbial strain.

To confirm the results from OD at $600 \mathrm{~nm}$ (Figure 1) clone formation counting assay was done. Interestingly found that there was significantly more bacteria in Enterobacter biofilm $\left(3.8 \times 10^{6} / \mathrm{ml}\right.$ day1) than in biofilm of Serretia $\left(2.6 \times 10^{6} / \mathrm{ml}\right.$ day1) after incubation period of $24 \mathrm{~h}$ at $37^{\circ} \mathrm{C}$ temperature (Figure 5 dark blue curve for Enterobacter and pink curve for Serretia). These results are in accordance with the published values [16].

\section{Conclusion}

The results of this study suggested that biofilm growth parameters vary for different organisms under single culture condition. Biofilm clone formation counting assay also supported these findings.

\section{References}

[1] Adegbola, R.A. and Old, D.C. (1982) New Fimbrial Hemagglutinin in Serratia Species. Infection and Immunity, 38, 306-315. http://www.ncbi.nlm.nih.gov/pmc/articles/PMC347733

[2] Roberts, D.P., Dery, P.D., Yucel, I. and Buyer, J.S. (1999) Importance of pfkA for Rapid Growth of Enterobacter cloacae during Colonization of Crop Seeds. Applied and Environmental Microbiology, 66, 87-91.

http://aem.asm.org/content/66/1/87.full http://dx.doi.org/10.1128/AEM.66.1.87-91.2000

[3] Ursua, P.R., Unzaga, M.J. and Melero, P. (1996) Serratia rubidaea as an Invasive Pathogen. Journal of Clinical Microbiology, 34, 216-217. http://jcm.asm.org/content/34/1/216

[4] Hoffmann, H. and Roggenkamp, A. (2003) Population Genetics of the Nomenspecies Enterobacter cloacae. Applied and Environmental Microbiology, 69, 5306-5318. http://aem.asm.org/content/69/9/5306

http://dx.doi.org/10.1128/AEM.69.9.5306-5318.2003

[5] Charaeklis, W.C. (1990) Microbial Fouling and Microbial Biofouling Control. In: Characklis, W.C. and Marshall, K.C., Eds., Biofilms, John Wiley, New York, 523-634.

[6] Criado, M.T., Suarez, B. and Ferreros, C.M. (1994) The Importance of Bacterial Adhesion in Dairy Industry. Journal of Food Technology, 48, 123-126.http://agris.fao.org/agris-search/search.do?recordID=US19950029470

[7] Zottola, E.A. and Sasahara, K.C. (1994) Microbial Biofilms in the Food Processing Industry—Should They Be a Concern. International Journal of Food Microbiology, 23, 125-148.

http://www.sciencedirect.com/science/article/pii/0168160594900477 http://dx.doi.org/10.1016/0168-1605(94)90047-7

[8] Pompermayer, D.M.C. and Gaylarde, C.C. (2000) The Influence of Temperature on the Adhesion of Mixed Cultures of Staphylococcus aureus and Escherichia coli to Polypropylene. Journal of Food Microbiology, 17, 361-365. http://www.sciencedirect.com/science/article/pii/S0740002099902915 http://dx.doi.org/10.1006/fmic.1999.0291

[9] Costerton, J.W. (1999) Introduction to Biofilm. International Journal of Antimicrobial Agents, 11, $217-221$. http://www.sciencedirect.com/science/article/pii/S0924857999000187 http://dx.doi.org/10.1016/S0924-8579(99)00018-7

[10] Bauer, T.T., Torres, A., Ferrer, R., Heyer, C.M., Schultze-Werninghaus, G. and Rasche, K. (2002) Biofilm Formation in Endotracheal Tubes. Association between Pneumonia and the Persistence of Pathogens. Monaldi Archives for Chest Disease, 57, 84-87. http://archest.fsm.it/pne/pdf/57/1/pne_57_1_14.pdf

[11] Slinger, R., Chan, F., Ferris, W., Yeung, S.W., St-Denis, M., Gaboury, I. and Aaron, S.D. (2006) Multiple Combina- 
tion Antibiotic Susceptibility Testing of Non-Typeable Haemophilus Influenzae Biofilms. Diagnostic Microbiology and Infectious Disease, 56, 247-253.http://www.sciencedirect.com/science/article/pii/S0732889306001659

[12] Buchanon, U.R.E. and Gibbons, N.E. (1974) Bergey’s Manual of Determinative Bacteriology. 8th Edition, The Williams and Wilkins Company Ltd., Baltomore, 22-35.

[13] Christensen, G.D., Simpson, W.A., Bisno, A.L. and Beachey, E.H. (1982) Adherence of Slime-Producing Strains of Staphylococcus epidermidis to Smooth Surfaces. Infection and Immunity, 37, 318-326. http://www.ncbi.nlm.nih.gov/pmc/articles/PMC347529/

[14] Biørnstad, T.J. and Håvarstein, L.S. (2011) ClpC Acts as a Negative Regulator of Competence in Streptococcus thermophiles. Microbiology, 157, 1676-1684. http://www.ncbi.nlm.nih.gov/pubmed/21436217 http://dx.doi.org/10.1099/mic.0.046425-0

[15] Collins, C.H. and Lyne, P.M. (1984) Microbiological Methods. 5th Edition, Butterworths Co. Ltd., London, 56-113.

[16] Liu, L., Chu, L., Liu, Q., Wang, C., Xia, Y. and Peng, Y. (2010) A Comparative Study on Biofilm Formation of Nontypeable Haemophilus influenzae and Pseudomonas aeruginosa under Single Culture or Co-Culture. African Journal of Microbiology Research, 4, 180-184.

http://www.academicjournals.org/journal/AJMR/article-abstract/E555B8B11618 